\title{
Submicroscopic chromosomal imbalances contribute to early abortion
}

\author{
Haibo Li ${ }^{\dagger}$, Minjuan Liư ${ }^{\dagger}$, Min Xie, Qin Zhang, Jingjing Xiang, Chengying Duan, Yang Ding, Yinghua Liu, Jun Mao, \\ Ting Wang ${ }^{*}$ and Hong Li* (i)
}

\begin{abstract}
Background: Chromosomal abnormalities are one of the genetic mechanisms associated with abortion. However, the roles of submicroscopic chromosomal imbalances in early abortion are still unclear. This study aims to find out whether submicroscopic chromosomal imbalances contribute to early abortion.

Methods: A total of 78 chorionic villus specimens from early spontaneous abortion patients with no obvious abnormality are collected after miccroassay analysis (the case group). At the same time, 60 chorionic villus specimens from induced abortion patients with no obvious abnormality are selected as the control group. The submicroscopic structures of chromosomes from two groups are analyzed using an array-based comparative genomic hybridization (aCGH).
\end{abstract}

Results: In the case group, 15 specimens show submicroscopic chromosomal abnormalities including 14 microdeletion/micro-duplication in chromosomes 2, 4, 5, 6, 7, 8, 9, 12, 15, 16, 18, and 22, and 1 uniparental disomy (UPD) in chromosome 19. Moreover, no pathogenic copy number variations are found in the control group. The results between these two groups exhibit significantly statistical difference.

Conclusion: Submicroscopic chromosomal imbalances may be one of the main reasons for early abortion.

Keywords: Chromosomal abnormality, Abortion, Chorionic villus, Karyotype analysis

\section{Background}

Spontaneous abortion, also known as miscarriage, means the loss of a pregnancy before 20 weeks and the weight of fetal less than $1000 \mathrm{~g}$, which is the natural death of an embryo before it can survive independently [1]. Risk factors for miscarriage include an older parent, previous miscarriage, drug or alcohol use, diabetes, exposure to tobacco smoke, and obesity, and so on [2]. Early abortion that occurs in the first 12 weeks of pregnancy, constitutes about $80 \%$ of miscarriages [3]. A large proportion of early abortion cases is caused by chromosomal abnormalities. Among them, half of embryonic miscarriages have an aneuploidy, namely aberrant number of chromosomes [4].

About $6-13 \%$ stillbirth is related to karyotypic alterations [5-7]. Karyotype analysis is reported to detect

\footnotetext{
*Correspondence: biowt@163.com; hongliszivf@163.com

${ }^{+}$Haibo Li and Minjuan Liu contributed equally to this work.

Center for Reproduction and Genetics, The Affiliated Suzhou Hospital of

Nanjing Medical University, NO. 26 Daoqian Street, Suzhou 215002, Jiangsu

Province, China
}

numerical abnormalities of chromosomes like triploid, haploid and polyploidy and structural abnormality like translocation and inversion. Therefore, the technique of G-binding karyotype analysis is usually used to diagnose the karyotype abnormality of tissues in the dead fetus [8]. However, due to weak cell viability of died fetus and difficult culture of cells, only $45-65 \%$ of cells can be obtained for the diagnosis of cytogenetics [9]. Recent researches have found that submicroscopic structure copy number variations (CNVs) is the genetic etiology of fetal growth retardation, miscarriage, stillbirth and other congenital diseases, which can be detected by the technique of chromosomal microarray analysis (CMA) [10, 11].

CMA, also called molecular karyotyping analysis, includes array-based comparative genomic hybridization (aCGH), and single nucleotide polymorphism (SNP) array $[12,13]$. By far, CMA has been used in the research and diagnosis of tumors [14], neurologic and mental diseases [15-17], and congenital diseases [18, 19], etc. However, there are few reports about CMA analysis in miscarriage 
and stillbirth. In the present study, in order to determine whether submicroscopic chromosomal imbalances are the main reasons for early abortion CMA is used to analyze and compare the submicroscopic structures of chromosomes in chorionic villus specimens from both the early spontaneous abortion group and the induced abortion group.

\section{Methods}

\section{Patients}

A total of 78 chorionic villus specimens from early spontaneous abortion patients with no obvious abnormality (the case group) and 60 chorionic villus specimens from induced abortion patients with no obvious abnormality (the control group) were collected by the Center for Reproduction and Genetics (The affiliated Suzhou Hospital of Nanjing Medical University, Suzhou, Jiangsu, China) after karyotype analysis. All experiments were carried out with the approval of the Institutional Ethics Commission.

\section{Array-CGH}

The $8 * 60 \mathrm{k}$ aCGH analysis (Agilent Technologies, Santa Clara, CA, custom-designed) was performed according to the manufacturer's protocols (version 4.0, Agilent Technologies, CA, USA). Briefly, $0.5 \mu \mathrm{g}$ of genome DNA
(gDNA) was digested with an enzyme mixed with $2.5 \mathrm{U}$ Alu I and 2.5 U Rsa I (SureTag DNA Labeling Kit, Agilent Technologies, CA, USA) at $37{ }^{\circ} \mathrm{C}$ for $2 \mathrm{~h}$. gDNA was labeled with Cy3 and Cy5 (test and control, respectively), and further purified with SureTag DNA Labeling Kit (Agilent Technologies, CA, USA) following the instructions provided by the company. The $60 \mathrm{~K}$ whole genome aCGH chip containing one oligoprobe/ $8 \mathrm{~kb}$ (Agilent Technologies) was hybridized with labeled DNA at $65{ }^{\circ} \mathrm{C}$ for $24 \mathrm{~h}$.

\section{Image and data analysis}

The hybridized chip was scanned, and images were quantified with FEATURE EXTRACTION software (Agilent Technologies). Data were normalized using a vendor-provided equation ( $\log 2[\mathrm{Cy} 3 / \mathrm{Cy} 5]$ 0.25). CNVs selection was conducted in Agilent CytoGenomics (Agilent Technologies), followed by a filter to select regions with three or more adjacent probes and a minimum average $\log 2$ ratio +0.25 .

\section{Result}

The results of aCGH show deletion as well as duplication in different genomic regions affected early spontaneous abortion. In the case group, 15 specimens with chromosomal abnormalities including 14 micro-deletion/

Table 1 The results of aCGH in 15 patients

\begin{tabular}{|c|c|c|}
\hline Patients & The results of aCGH & Number of CNVs \\
\hline 1 & $\begin{array}{l}\text { Chr16: (76,320,001-90,160,000) X3,13.84 M, 16q terminal duplication } \\
\text { syndrome; Chr18: }(56,020,001-78,020,000) \times 1,22 \mathrm{M}, 18 \mathrm{q} \text { deletion } \\
\text { syndrome. }\end{array}$ & $2(35.84)$ \\
\hline 2 & Chr 6p25.3-p22.3 (347,038-17,543,199) x1, 17.20 M deletion syndrom. & $1(17.20)$ \\
\hline 3 & Chr 19 uniparental disomy. & \\
\hline 4 & $\begin{array}{l}\text { Chr22: (18,900,001-21,420,000) X1, } 2.52 \text { M, 22q11 deletion syndrome } \\
\text { (Velocardiofacial/DiGeorge syndrome). }\end{array}$ & $1(2.52)$ \\
\hline 5 & $\begin{array}{l}\text { Chr22: (18,880,001-21,460,000) X1, } 2.58 \text { M, 22q11 deletion syndrome } \\
\text { (Velocardiofacial / DiGeorge syndrome). }\end{array}$ & $1(2.58)$ \\
\hline 6 & Chr22: $(35,420,001-39,100,000) X 1,3.68$ M, Waardenburg syndrome. & $1(3.68)$ \\
\hline 7 & $\begin{array}{l}\text { Chr22: (18,880,001-21,820,000) X1, } 2.94 \text { M, 22q11 deletion syndrome } \\
\text { (Velocardiofacial / DiGeorge syndrome). }\end{array}$ & $1(2.94)$ \\
\hline 8 & Chr9: $(130,900,001-133,080,000) \times 1,2.18 \mathrm{M}$. & $1(2.18)$ \\
\hline 9 & $\begin{array}{l}\text { Chr7: }(64,680,001-65,200,000) \times 1,520 \text { K, deletion syndrome; Chr12: } \\
\text { 160,001-34,820,000) X3, 34.66 M, 12p duplication syndrome. }\end{array}$ & $2(35.18)$ \\
\hline 10 & $\begin{array}{l}\text { Chr16: }(76,320,001-90,160,000) \times 3,13.84 \mathrm{M}, 16 \mathrm{q} \text { terminal duplication } \\
\text { syndrome; Chr18: }(56,020,001-78,020,000) \times 1,22 \mathrm{M}, 18 \mathrm{q} \text { deletion } \\
\text { syndrome. }\end{array}$ & $2(35.84)$ \\
\hline 11 & $\begin{array}{l}\text { Chr15: }(22,740,001-29,120,000) \times 1,6.38 \text { M, Prader-Willi syndrome, } \\
\text { Angelman syndrome. }\end{array}$ & $1(6.38)$ \\
\hline 12 & $\begin{array}{l}\text { Chr18: }(66,540,001-68,040,000) \times 3,1.5 \mathrm{M} \text {, duplication, pathogenicity } \\
\text { unknown; Chr18: }(68,760,001-77,400,000) \times 3,8.64 \mathrm{M}, 18 q \text { terminal } \\
\text { duplication syndrome. }\end{array}$ & $2(10.14)$ \\
\hline
\end{tabular}


Table 1 The results of aCGH in 15 patients (Continued)

\begin{tabular}{|c|c|c|}
\hline Patients & The results of aCGH & Number of CNVs \\
\hline 13 & $\begin{array}{l}\text { Chr16: (76,260,001-90,160,000) X3, 13.9 M, 16q terminal duplication } \\
\text { syndrome; Chr18: }(56,080,001-78,020,000) \text { X1, 21.94 M, 18q deletion } \\
\text { syndrome. }\end{array}$ & $2(35.84)$ \\
\hline 14 & $\begin{array}{l}\text { Chr2: }(1-24,020,000) \times 3,24.02 \mathrm{M}, 2 \mathrm{p} \text { partial trisomy syndrome; Chr5: } \\
\text { (19,080,001-19,460,000) X1, } 380 \mathrm{~K} \text {, deletion, pathogenicity unknown; } \\
\text { Chr8: }(160,001-8,100,000) \times 1,7,94 \mathrm{M} \text {, deletion syndrome Cornelia } \\
\text { de Lange syndrome; Chr8: }(12,540,001-24,660,000) \times 3,12.12 \mathrm{M} \text {, } \\
\text { duplication; pathogenicity unknown. }\end{array}$ & $4(44.46)$ \\
\hline 15 & $\begin{array}{l}\text { Chr2: }(160,940,001-243,020,000) \times 3,82.08 \mathrm{M}, 2 \mathrm{q} \text { terminal duplication } \\
\text { syndrome; Chr4: }(184,020,001-190,940,000) \times 1,6.92 \mathrm{M} \text {, 4q terminal } \\
\text { deletion syndrome. }\end{array}$ & $2(89)$ \\
\hline
\end{tabular}

micro-duplication and 1 uniparental disomy for chromosome 19 are found among 78 specimens (Table 1). The length of abnormality of 15 specimens ranges from $380 \mathrm{~kb}$ to $82.08 \mathrm{mb}$. The aberrations are unequally distributed among the 15 patients, for example, patient 14 has 4 aberrations. Furthermore, the number of CNVs in patients 14 and 15 are higher than that of other patients (Table 1). The CNV plots of one patient are shown in Additional file 1: Figure $\mathrm{S} 1$ as a representative. Conversely, no pathogenic CVNs are found in the control group.
Those chromosomal aberrations are not equally distributed in all chromosomes. The submicroscopic chromosomal abnormalities occur in chromosome 2, 4, 5, 6, 7, 8, 9, 12, 15, 16, 18, and 22 (Table 2). Among them, the submicroscopic chromosomal abnormalities of chromosome 4, 8, 9, 18, and 22 have ever been reported by others. A total of 9 amplification events and 14 deletion events are invovled in 15 patients. Twenty-one pathogenic CNVs including Waardenburg syndrome, Velocardiofacial/ DiGeorge syndrome, Prader-Willi syndrome, Angelman syndrome, and Cornelia de Lange syndrome are found.

Table 2 The results of aCGH per chromosome

\begin{tabular}{|c|c|c|c|c|}
\hline Chromosome & Patients & The results of aCGH & References & Number of CNVs \\
\hline 2 & 14,15 & $\begin{array}{l}\text { 14: chr2, 24.02 M 2p partial trisomy syndrome pathogenicity } \\
\text { unknown; 15: chr2, 82.08 M 2q terminal duplication syndrome. }\end{array}$ & - & 2 \\
\hline 4 & 15 & Chr4, $6.92 \mathrm{M} \mathrm{4q}$ terminal deletion syndrome. & [27] & 1 \\
\hline 5 & 14 & Chr5, $380 \mathrm{~K}$ deletion, pathogenicity unknown. & - & 1 \\
\hline 6 & 2 & Arr6, 17.20 M deletion syndrome. & - & 1 \\
\hline 7 & 9 & Chr7, $520 \mathrm{~K}$ deletion syndrome. & - & 1 \\
\hline 8 & 14 & $\begin{array}{l}\text { Chr8, 7.94 M deletion syndrome, Cornelia de Lange syndrome; } \\
\text { Chr8, 12.12 M duplication, pathogenicity unknown. }\end{array}$ & [28] & 1 \\
\hline 9 & 8 & Chr9, $2.18 \mathrm{M}$, deletion syndrome. & [29] & 1 \\
\hline 12 & 9 & Chr12, 34.66 M 12p duplication syndrome. & - & 1 \\
\hline 15 & 11 & $\begin{array}{l}\text { Chr15, } 6.38 \mathrm{M} \text {, deletion syndrome, Prader-Willi syndrome, } \\
\text { Angelman syndrome. }\end{array}$ & - & 1 \\
\hline 16 & $1,10,13$ & $\begin{array}{l}\text { 1: chr16, } 13.84 \text { M terminal duplication syndrome; } 10: \text { chr16, } \\
\text { 13.84 M 16q terminal duplication syndrome; } 13 \text { : chr16, } 13.9 \\
\text { M 16q terminal duplication syndrome. }\end{array}$ & - & 3 \\
\hline 18 & $1,10,12,13$ & $\begin{array}{l}\text { 1: chr18, } 22 \text { M deletion syndrome; } 10 \text { : chr18, } 22 \mathrm{M} 18 \mathrm{q} \\
\text { deletion syndrome; } 12 \text { : chr18, } 1.5 \mathrm{M} 18 \mathrm{q} \text { terminal duplication, } \\
\text { pathogenicity unknown; chr18, } 8.64 \mathrm{M} 18 \mathrm{q} \text { terminal duplication } \\
\text { syndrome; } \\
\text { 13: chr18,21.94 M 18q deletion syndrome. }\end{array}$ & [30] & 4 \\
\hline 19 & 3 & Chr 19 uniparental disomy. & - & 1 \\
\hline 22 & $4,5,6,7$ & $\begin{array}{l}\text { 4: chr22, 2.52 M 22q11 deletion syndrome (Velocardiofacial/ } \\
\text { DiGeorge syndrome); 5: chr22, 2.58 M 22q11 deletion syndrome } \\
\text { (Velocardiofacial/DiGeorge syndrome); 6: chr22, } 3.68 \mathrm{M} \text { deletion } \\
\text { syndrome Waardenburg syndrome; 7: chr22, 2.94 M 22q11 } \\
\text { deletion syndrome (Velocardiofacial / } \\
\text { DiGeorge syndrome). }\end{array}$ & [31] & 4 \\
\hline
\end{tabular}

"_" means no investigation by others 
22q11 (18900001-21,420,000) occurs 2.52 M deletion syndrome, which leads to Velocardiofacial/DiGeorge syndrome. Besides, the pathogenicity of two CNVs on chromosomes 5 and 8 are still unknown. Amplifications frequently are identified in chromosomes 2, 16, 18 (77.78\%), and chromosomal deletions are more frequent in chromosomes 18 and $22(50.00 \%)$. The total frequency of submicroscopic chromosomal abnormalities appearing in chromosomes $2,16,18$, and 22 is $60.87 \%$ (Table 3 ).

\section{Discussion}

To elucidate the possible genetic reasons underlying the spontaneous abortion, we investigated chorionic villus specimens from early spontaneous abortion with no obvious abnormality using aCGH. Previously, the technique of G-binding karyotype analysis is regarded as the "Gold rule" of diagnosis of the chromosome abnormality, which can be used to test a set of chromosome number and obvious textural anomaly. However, this method has multiple limitations such as the failure of cell culture, time-consuming cell culture, microorganism pollution and the selective growth of maternal decidual cells. Besides, it has low resolution, hardly detects CNVs less than $5 \mathrm{Mb}$, and difficultly makes sure the size and breaking point of CNVs [20-24]. Other techniques, like fluorescence in situ hybridization (FISH) and CGH, are rarely applied due to their limitations. In contrast, CMA has the advantages including no need to culture cells, high throughput, high resolution and high accuracy, and it can scan the chromosomal non-equilibrium variations within the whole genome and detect CNVs at the submicroscopic structure level through one time hybrid experiment $[25,26]$. Further, CMA improves diagnosis of chromosomal diseases at the genetic level avoiding the limitation of karyotype, FISH and CGH analysis techniques. aCGH analysis technology is mainly used in the diagnosis and research in cancers and genetic diseases $[20,21,27,28]$, but less in abortion. In this study, aCGH method is successfully used to determine submicroscopic chromosomal abnormalities in early spontaneous abortion patients.

Previous studies indicated that the submicroscopic chromosomal abnormalities is one of the major genetic causes of abortion and stillbirth [14, 25, 26]. Especially, stillbirth karyotypes are found at different trimesters. In 78 uncultured amniotic fluid specimens during second trimester, chromosomal abnormality is found using probes located at chromosome 13, 18, 21, X, Y. by FISH method [29]. Du et al. reported that absent fetal nasal bone and a higher rate of abnormal karyotype are included in the second trimester of pregnant women [30]. Microarray analysis is used to identiy stillbirths and provids a relative increase in the diagnosis of genetic abnormalities of compared to karyotype analysis [31]. Sahoo et al. [32] used a whole-genome SNP-based array (81.6\%) and aCGH to determine the abnormalities in both fresh and formalin-fixed paraffin-embedded (FFPE) samples of products of conception (POCs) [33]. In this study, 15 submicroscopic chromosomal abnormalities are observed in early spontaneous abortion with using chorionic villus samples by aCGH method. Furthermore, micro-deletion/micro-duplication is observed in chromosomes $2,4,5,6,7,8,9,12,15,16,18$, and 22 , and uniparental disomy is found in chromosome 19. In addition, a total of 21 pathogenic CNVs including Waardenburg syndrome, Velocardiofacial/DiGeorge syndrome, Prader-Willi syndrome, Angelman syndrome, and Cornelia de Lange syndrome identified in this study are also reported in published articles [32, 34-37]. For instance, SPTAN1 gene deletion in chromosome

Table 3 Number and frequency of aberrations per chromosome

\begin{tabular}{llllll}
\hline Chromosome & Duplication(Patients) & Frequency (\%) & Deletions (Patients) & Frequency (\%) & Total Frequency(\%) \\
\hline 2 & 14,15 & 22.22 & - & & 8.70 \\
4 & - & & 15 & 7.14 & 4.35 \\
5 & - & & 14 & 7.14 & 4.35 \\
6 & - & 2 & 7.14 & 4.35 \\
7 & - & 9 & 7.14 & 4.35 \\
8 & 14 & 11.11 & 14 & 7.14 & 8.70 \\
9 & - & & & 4.35 \\
12 & 9 & 11.11 & - & 4.35 \\
15 & - & 11 & & 4.35 \\
16 & $1,10,13$ & - & & 13.04 \\
18 & 12,12 & 33.33 & $1,10,13$ & 21.43 \\
19 & - & 22.22 & - & 21.74 \\
\hline
\end{tabular}

"_" means no amplification or deletion 
9:(130900001-133,080,000) has been reported to be associated with early infantile epileptic encephalopathy, infantile spasms, intellectual disability, and hypomyelination, and molecular defects of TOR1A gene lead to early-onset primary dystonia [31]. Besides, two novel CNVs on chromosomes 5 and 8 [chr5: (1908000119,460,000) × 1, $380 \mathrm{~K}$; chr8: $(12540001-24,660,000) \mathrm{X} 3$, $12.12 \mathrm{M}$ ] provide more possible causative CNVs in the development of abortion. Additionally, the spontaneous abortion alterations target certain chromosomes more than others. The CNVs of chromosomes 2, 16, 18, and 22 account for more than half of the cases (60.87\%) in the present study.

\section{Conclusion}

In sumarry, the aCGH analysis of 78 chorionic villus specimens shows that submicroscopic chromosomal imbalances might be one of the main reasons for early abortion. The chromosomal regions identified in this study may be critical in the development of abortion, and provides a basis for better understanding of the genetic cause of abortion. However, Further investigations are needed to including exploring the possible causative $\mathrm{CNVs}$ and genes including more samples and more comprehensive clinical information of the patients.

\section{Additional file}

Additional file 1: Figure S1. The CNV plots of one patient are shown in Figure $\mathbf{S} 1$ as a representative. (TIF $396 \mathrm{~kb}$ )

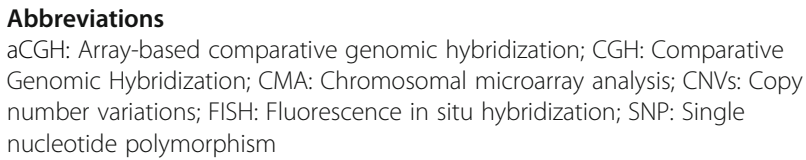
Genomic Hybridization; CMA: Chromosomal microarray analysis; CNVs: Copy number variations; FISH: Fluorescence in situ hybridization; SNP: Single nucleotide polymorphism

\section{Acknowledgements}

We thank the patients for participating in this research project. The authors also acknowledge all members of the laboratory.

\section{Funding}

This work is supported by Jiangsu Province Association of Maternal and Child Health Project (FYX201603); Jiangsu Provincial commission of health and family planning (No.H2017073); Jiangsu Provincial Medical Youth Talent (QNRC2016238); and Suzhou Industry Technology Innovation Project (SYS201770; KJXW2015022).

\footnotetext{
Authors' contributions

$H L$ is resposible for the guarantor of integrity of the entire study, study concepts and design, literature research, data acquisition and analysis, statistical analysis, and manuscript preparation and editing; $\mathrm{ML}$ is the guarantor of integrity of the entire study, literature research, data acquisition and analysis, statistical analysis; MX undertakes the literature research, and statistical analysis; QZ is involved in the clinical studies; JX, YL and JM are responsible for the definition of intellectual content and experimental studies; CD and YD investigate the definition of intellectual content and the clinical studies; TW and HL are responsible for the study concepts, manuscript editing and manuscript review. All authors approve to submit the manuscript in this edition.
}

Ethics approval and consent to participate

The study was approved by the ethic committee. Informed consent was obtained.

\section{Competing interests}

The authors declare that they have no competing interests.

\section{Publisher's Note}

Springer Nature remains neutral with regard to jurisdictional claims in published maps and institutional affiliations.

Received: 6 March 2018 Accepted: 24 May 2018

Published online: 21 July 2018

\section{References}

1. Muttukrishna S, Jauniaux E, Greenwold N, McGarrigle H, Jivraj S, Carter S, Elgaddal S, Groome N, Regan L. Circulating levels of inhibin a, activin a and follistatin in missed and recurrent miscarriages. Hum Reprod. 2002;17:3072-8.

2. Oliver A, Overton C. Diagnosis and management of miscarriage. Practitioner. 2014:258:25-8.

3. Vaiman D. Genetic regulation of recurrent spontaneous abortion in humans. Biom J. 2015:38:11-24.

4. Sugiura-Ogasawara M, Ozaki Y, Katano K, Suzumori N, Kitaori T, Mizutani E. Mizutani, Abnormal embryonic karyotype is the most frequent cause of recurrent miscarriage. Hum Reprod. 2012;27:2297-303.

5. Ballif BC, Kashork CD, Saleki R, Rorem E, Sundin K, Bejjani BA, Shaffer LG. Detecting sex chromosome anomalies and common triploidies in products of conception by array-based comparative genomic hybridization. Prenat Diagn. 2006;26:333-9.

6. Goddijn M, Leschot NJ. Genetic aspects of miscarriage. Baillieres Best Pract Res Clin Obstet Gynaecol. 2000;14:855-65.

7. Nagaishi M, Yamamoto T, linuma K, Shimomura K, Berend SA, Knops J. Chromosome abnormalities identified in 347 spontaneous abortions collected in Japan. J Obstet Gynaecol Res. 2004;30:237-41.

8. Rajcan-Separovic E, Diego-Alvarez D, Robinson WP, Tyson C, Qiao Y, Harvard C, Fawcett C, Kalousek D, Philipp T, Somerville MJ, Stephenson MD. Identification of copy number variants in miscarriages from couples with idiopathic recurrent pregnancy loss. Hum Reprod. 2010;25:2913-22.

9. Raca G, Artzer A, Thorson L, Huber S, Modaff P, Laffin J, Pauli RM. Arraybased comparative genomic hybridization $(\mathrm{aCGH})$ in the genetic evaluation of stillbirth. Am J Med Genet A. 2009;149A:2437-43.

10. Levy B, Wapner R. Prenatal diagnosis by chromosomal microarray analysis. Fertil Steril. 2018;109(2):201-12.

11. Xia Y, Yang Y, Huang S, Wu Y, Li P, Zhuang J. Clinical application of chromosomal microarray analysis for the prenatal diagnosis of chromosomal abnormalities and copy number variations in fetuses with congenital heart disease. Prenat Diagn. 2018. In press.

12. Brady PD, Vermeesch JR. Genomic microarrays: a technology overview. Prenat Diagn. 2012;32:336-43.

13. Breman A, Pursley AN, Hixson P, Bi W, Ward P, Bacino CA, Shaw C, Lupski JR, Beaudet A, Patel A, Cheung SW, Van den Veyver I. Prenatal chromosomal microarray analysis in a diagnostic laboratory; experience with $>1000$ cases and review of the literature. Prenat Diagn. 2012;32:351-61.

14. Rassekh SR, Chan S, Harvard C, Dix D, Qiao Y, Rajcan-Separovic E. Screening for submicroscopic chromosomal rearrangements in Wilms tumor using whole-genome microarrays. Cancer Genet Cytogenet. 2008;182:84-94.

15. Vissers LE, de Vries BB, Veltman JA. Genomic microarrays in mental retardation: from copy number variation to gene, from research to diagnosis. J Med Genet. 2010:47:289-97.

16. Shaw-Smith C, Redon R, Rickman L, Rio M, Willatt L, Fiegler $H$, Firth $H$, Sanlaville D, Winter R, Colleaux L, Bobrow M, Carter NP. Microarray based comparative genomic hybridisation (array-CGH) detects submicroscopic chromosomal deletions and duplications in patients with learning disability/ mental retardation and dysmorphic features. J Med Genet. 2004;41:241-8.

17. Singleton $A B$, Farrer $M$, Johnson J, Singleton A, Hague $S$, Kachergus J, Hulihan M, Peuralinna T, Dutra A, Nussbaum R, Lincoln S, Crawley A, Hanson M, Maraganore D, Adler C, Cookson MR, Muenter M, Baptista M, Miller D, Blancato J, Hardy J, Gwinn-Hardy K. alpha-Synuclein locus triplication causes Parkinson's disease. Science. 2003;302:841.

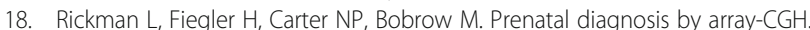
Eur J Med Genet. 2005;48:232-40. 
19. Wapner RJ, Martin CL, Levy B, Ballif BC, Eng CM, Zachary JM, Savage M, Platt LD, Saltzman D, Grobman WA, Klugman S, Scholl T, Simpson JL, McCall K, Aggarwal VS, Bunke B, Nahum O, Patel A, Lamb AN, Thom EA, Beaudet AL, Ledbetter DH, Shaffer LG, Jackson L. Chromosomal microarray versus karyotyping for prenatal diagnosis. N Engl J Med. 2012;367:2175-84.

20. Lomax B, Tang S, Separovic E, Phillips D, Hillard E, Thomson T, Kalousek DK. Comparative genomic hybridization in combination with flow cytometry improves results of cytogenetic analysis of spontaneous abortions. Am J Hum Genet. 2000;66:1516-21.

21. Menasha J, Levy B, Hirschhorn K, Kardon NB. Incidence and spectrum of chromosome abnormalities in spontaneous abortions: new insights from a 12-year study. Genet Med. 2005;7:251-63.

22. van den Berg MM, van Maarle MC, van Wely M, Goddijn M. Genetics of early miscarriage. Biochim Biophys Acta. 2012;1822:1951-9.

23. Korteweg FJ, Bouman K, Erwich JJ, Timmer A, Veeger NJ, Ravisé JM, Nijman $\mathrm{TH}$, Holm JP. Cytogenetic analysis after evaluation of 750 fetal deaths: proposal for diagnostic workup. Obstet Gynecol. 2008;111:865-74.

24. Menten B, Swerts K, Delle Chiaie B, Janssens S, Buysse K, Philippé J, Speleman F. Array comparative genomic hybridization and flow cytometry analysis of spontaneous abortions and mors in utero samples. BMC Med Genet. 2009;10:89.

25. Reddy UM, Page GP, Saade GR. The role of DNA microarrays in the evaluation of fetal death. Prenat Diagn. 2012;32:371-5.

26. Viaggi CD, Cavani S, Malacarne M, Floriddia F, Zerega G, Baldo C, Mogni M, Castagnetta M, Piombo G, Coviello DA, Camandona F, Lijoi D, Insegno W, Traversa M, Pierluigi M. First-trimester euploid miscarriages analysed by array-CGH. J Appl Genet. 2013:54:353-9.

27. Guerneri S, Bettio D, Simoni G, Brambati B, Lanzani A, Fraccaro M. Prevalence and distribution of chromosome abnormalities in a sample of first trimester internal abortions. Hum Reprod. 1987;2:735-9.

28. Ohno M, Maeda T, Matsunobu A. A cytogenetic study of spontaneous abortions with direct analysis of chorionic villi. Obstet Gynecol. 1991;77:394-8.

29. Vona B, Nanda I, Neuner C, Schröder J, Kalscheuer VM, Shehata-Dieler W, Haaf T. Terminal chromosome $4 q$ deletion syndrome in an infant with hearing impairment and moderate syndromic features: review of literature. BMC Med Genet. 2014;15:72.

30. Zhang YP, Wu JP, Li XT, Lei CX, XU JZ, Yin M. Karyotype analysis of amniotic fluid cells and comparison of chromosomal abnormality rate during second trimester. Zhonghua Fu Chan Ke Za Zhi. 2011;46(9):644-8.

31. Du Y, Ren Y, Yan Y, Cao L. Absent fetal nasal bone in the second trimester and risk of abnormal karyotype in a prescreened population of Chinese women. Acta Obstet Gynecol Scand. 2018;97(2):180-6.

32. Reddy UM, Page GP, Saade GR, Silver RM, Thorsten VR, Parker CB, Pinar $H$, Willinger M, Stoll BJ, Heim-Hall J, Varner MW, Goldenberg RL, Bukowski R, Wapner RJ, Drews-Botsch CD, O'Brien BM, Dudley DJ, Levy B, Stillbirth Collaborative Research Network NICHD. Karyotype versus microarray testing for genetic abnormalities after stillbirth. N Engl J Med. 2012;367(23):2185-93.

33. Sahoo T, Dzidic N, Strecker MN, Commander S, Travis MK, Doherty C, Tyson RW, Mendoza AE, Stephenson M, Dise CA, Benito CW, Ziadie MS, Hovanes K. Comprehensive genetic analysis of pregnancy loss by chromosomal microarrays: outcomes, benefits, and challenges. Genet Med. 2017:19(1):83-9.

34. Baynam G, Goldblatt J, Walpole I. Deletion of 8p23.1 with features of Cornelia de Lange syndrome and congenital diaphragmatic hernia and a review of deletions of 8p23.1 to 8pter? A further locus for Cornelia de Lange syndrome. Am J Med Genet A. 2008;146A:1565-70.

35. Campbell IM, Yatsenko SA, Hixson P, Reimschisel T, Thomas M, Wilson W, Dayal U, Wheless JW, Crunk A, Curry C, Parkinson N, Fishman L, Riviello JJ, Nowaczyk MJ, Zeesman S, Rosenfeld JA, Bejjani BA, Shaffer LG, Cheung SW, Lupski JR, Stankiewicz P, Scaglia F. Novel 9q34.11 gene deletions encompassing combinations of four Mendelian disease genes: STXBP1, SPTAN1, ENG, and TOR1A. Genet Med. 2012;14:868-76.

36. Özsu E, Mutlu GY, Yüksel AB, Hatun \$. Features of two cases with 18a deletion syndrome. J Clin Res Pediatr Endocrinol. 2014;6:51-4.

37. Jelena B, Christina L, Eric V, Fabiola QR. Phenotypic variability in Waardenburg syndrome resulting from a 22q12.3-q13.1 microdeletion involving SOX10. Am J Med Genet A. 2014;164A:1512-9.

\section{Ready to submit your research? Choose BMC and benefit from:}

- fast, convenient online submission

- thorough peer review by experienced researchers in your field

- rapid publication on acceptance

- support for research data, including large and complex data types

- gold Open Access which fosters wider collaboration and increased citations

- maximum visibility for your research: over $100 \mathrm{M}$ website views per year

At BMC, research is always in progress.

Learn more biomedcentral.com/submissions 